\begin{tabular}{|c|c|}
\hline Title & Thin Film Fuel Cell Based on Nanometer-Thick Membrane of A morphous Zirconium Phosphate Electrolyte \\
\hline Author(s) & A oki, Y .; Fukunaga, Y .; Habazaki, H.; Kunitake, T. \\
\hline Citation & $\begin{array}{l}\text { Journal of the Electrochemical Society, 158(8), B866-B870 } \\
\text { https://doi.org/10.1149/1.3595388 }\end{array}$ \\
\hline Issue Date & 2011-06-06 \\
\hline Doc URL & http:/hdl .handle.net/2115/46798 \\
\hline Rights & $\begin{array}{l}\text { (1) The Electrochemical Society, Inc. 2011. All rights reserved. Except as provided under U.S. copyright law, this work } \\
\text { may not be reproduced, resold, distributed, or modified without the express permission of The Electrochemical Society } \\
\text { (ECS). The archival version of this work was published in J. Electrochem. Soc., 158(8), B866-B870, (2011) }\end{array}$ \\
\hline Type & article \\
\hline File Information & JES158-8_B866-B870.pdf \\
\hline
\end{tabular}

Instructions for use 


\title{
Thin Film Fuel Cell Based on Nanometer-Thick Membrane of Amorphous Zirconium Phosphate Electrolyte
}

\author{
Y. Aoki, ${ }^{a, z}$ Y. Fukunaga, ${ }^{a}$ H. Habazaki, ${ }^{a}, *$ and T. Kunitake ${ }^{b}$ \\ ${ }^{a}$ Faculty of Engineering, Hokkaido University, Sapporo, Hokkaido 060-8628, Japan \\ ${ }^{b}$ NanoMembrane Technologies, Inc., Wako 351-0104, Japan
}

\begin{abstract}
Novel thin film fuel cell based on the $100 \mathrm{~nm}$-thick electrolyte of amorphous $\mathrm{ZrP}_{2.6} \mathrm{O}_{x}$, working at $400^{\circ} \mathrm{C}$, was demonstrated. The hydrogen permeable membrane fuel cell (HMFC) using a Pd foil as a nonporous solid anode was fabricated. Ni interlayer of several hundreds nm thickness was introduced between the $\mathrm{Pd}$ anode and the $\mathrm{ZrP}_{2.6} \mathrm{O}_{x}$ electrolyte in order to suppress the deterioration of the electrolyte nanofilm by the deformation of the Pd anode during hydrogen absorption. In the $\mathrm{ZrP}_{2.6} \mathrm{O}_{x}$ electrolyte the transport number of proton was unity at $400^{\circ} \mathrm{C}$ as determined by an EMF measurement. The modification of the Ni anode surface by an ultrathin Pt or Pd layer effectively decreased the anode/electrolyte interfacial polarization. Consequently, the HMFC revealed the $\mathrm{OCV}$ of $1.0 \mathrm{~V}$ and the maximum power density of $1.8 \mathrm{~mW} \mathrm{~cm}^{-2}$ at $400^{\circ} \mathrm{C}$.

(C) 2011 The Electrochemical Society. [DOI: 10.1149/1.3595388] All rights reserved.
\end{abstract}

Manuscript submitted March 23, 2011; revised manuscript received April 29, 2011. Published June 6, 2011.

Fuel cells with a high power density operating at intermediate temperatures $\left(100-500^{\circ} \mathrm{C}\right)$ are promising as an ideal power source for future vehicles, a distributed generator and so on. For this reason, extensive research has been conducted to develop the solid oxide fuel cell (SOFC) with a nanometer-thick film electrolyte because reducing electrolyte thickness significantly decreases the ohmic loss at lower temperatures. ${ }^{1-6}$ We have previously reported that amorphous zirconium phosphate nanofilm, $a-\mathrm{ZrP}_{2.6} \mathrm{O}_{x}$, is a practically useful proton conductor with the area-specific resistance (ASR) of $<0.2 \Omega \mathrm{cm}^{2}$ in a temperature range from 200 to $400^{\circ} \mathrm{C}$ in dry atmosphere. ${ }^{7}$ Amorphous phases are advantageous as a thin film electrolyte because they tend to form the non-granular, denselypacked film without pinholes and clacks at elevated temperatures so that the gas crossover through the physical defects can be avoided during operation. In order to evaluate such a unique property, it is important to develop the thin film fuel cell with this amorphous oxide electrolyte. The main difficulty regarding a thin film fuel cell lies in fabricating solid thin film on porous electrode material. Recently, Ito et al. proposed a new conceptual fuel cell named the hydrogen membrane fuel cell (HMFC), which consists of an ultrathin proton conductor electrolyte supported on a dense hydrogen membrane metal anode. ${ }^{8,9}$ This fuel cell is advantageous for implementation of the thin film electrolyte because a much thinner electrolyte can be easily developed on a solid, non-porous metal support compared to a conventional porous support. In this study, we demonstrated that the HMFC using the amorphous, $100 \mathrm{~nm}$-thick film of $\mathrm{ZrP}_{2.6} \mathrm{O}_{x}$ electrolyte successfully generated electricity at $400^{\circ} \mathrm{C}$ and gave rise to the open circuit potential of about $1.0 \mathrm{~V}$. The predominant resistances of the fuel cell would be assigned to the proton transfer and the oxidative reaction at the anode/electrolyte solidsolid hetero interfaces.

\section{Experimental}

The fuel cells were constructed by depositing a $\mathrm{ZrP}_{2.6} \mathrm{O}_{x}$ electrolyte thin film on a hydrogen-permeable metal anode. The Pd foil (0.05 mm thickness, Tanaka Co.) was polished with the alumina particles (1.0 and $0.05 \mu \mathrm{m}$ diameter) and was cleaned by sonication in a pure water, ethanol and acetone. The Ni layer of $80-1200 \mathrm{~nm}$ thickness was sputter-deposited on the polished Pd foil surface so as to form a hydrogen-permeable Ni/Pd anode. In most cases, the thickness of the Ni layer was adjusted to $600 \mathrm{~nm}$. The surface of the $\mathrm{Ni} / \mathrm{Pd}$ anode was modified by depositing Pd or Pt ultrathin layers of about 5 nm thickness so as to form Pt@Ni/Pd and Pd@Ni/Pd anodes. The $\mathrm{ZrP}_{2.6} \mathrm{O}_{x}$ electrolyte membrane was prepared on the anode surface by multiple spin-coating of a mixed precursor solution of a

* Electrochemical Society Active Member.

${ }^{\mathrm{z}}$ E-mail: y-aoki@eng.hokudai.ac.jp zirconium tetra- $n$-butoxide $\left(\mathrm{Zr}(\mathrm{OBu})_{4}\right)$ (Kanto Chemical) and a phosphorus pentoxide $\left(\mathrm{P}_{2} \mathrm{O}_{5}\right)$ (Kanto Chemical) at the molar ratio of $\mathrm{Zr}: \mathrm{P}=1: 3$ with the metal concentration $(\mathrm{Zr}+\mathrm{P})$ adjusted in $50 \mathrm{mM}$. The detail of this procedure was reported elsewhere. ${ }^{7}$ The precursor sol was spin-coated onto the anode at $3000 \mathrm{rpm}$ for $20 \mathrm{~s}$ by a Mikasa 1H-D7 spin coater. The deposited gel layer was hydrolyzed by blowing hot air for $30 \mathrm{~s}$ (Iuchi hot gun), and the substrate was cooled to a room temperature by blowing cold air for $20 \mathrm{~s}$. These cycles of the spin-coating, hydrolysis and cooling were repeated 20 times and the gel film thus obtained was calcined at $430^{\circ} \mathrm{C}$ for $1 \mathrm{~h}$. A Pt particle layer $(50 \mathrm{~nm}$ thick, $1 \mathrm{~mm} \varphi)$ as a cathode was deposited on the $\mathrm{ZrP}_{2.6} \mathrm{O}_{x}$ electrolyte through a shadow mask so as to obtain metal/electrolyte/metal cell assembly.

The scanning electron microscopy (SEM) was carried out with JEOL JSM-7100F. The cross-sectional transmission electron microscopy (TEM) was performed by Hitachi HD-2000. The specimens for TEM observation was prepared by focused-ion-beam (FIB) (Hitachi FB-2100).

The performance of the $\mathrm{ZrP}_{2.6} \mathrm{O}_{x}$ thin film as a fuel cell electrolyte was evaluated by measuring the current-voltage $(I-V)$ relation at $400^{\circ} \mathrm{C}$. The measurements were carried out with a specificallydesigned sample folder, where the specimen was sealed by Al metal gasket in order to avoid mixing of the anode and cathode gases. To obtain temperature data as accurate as possible, a K-thermocouple was placed in close proximity to the cell. Normally, the $50 \%-\mathrm{H}_{2} / \mathrm{Ar}$ mixed gas was fed to the anode side of the sample sealed on a chamber at a flow rate of $200 \mathrm{~cm}^{3} \mathrm{~min}^{-1}$, and air $\left(20 \%-\mathrm{O}_{2} / \mathrm{Ar}\right.$ mixed gas $)$ was fed to the cathode side at a rate of $200 \mathrm{~cm}^{3} \mathrm{~min}^{-1}$. Electrochemical impedance spectra were obtained with Solartron 1260 in the frequency range of $10^{7}-0.1 \mathrm{~Hz}$ with ac amplitude of $10 \mathrm{mV}$. The analysis of the impedance spectra with an equivalent circuit model was carried out by the ZsimpWin program. Hydrogen permeation through the $\mathrm{Ni} / \mathrm{Pd}$ anode support was measured by detecting the hydrogen flow through the support with a quadrupole mass analyzer (Balzers, Prisma QMS200M). The Ni/Pd specimen was sealed on the same folder as that for the fuel cell measurements and hydrogen was submitted to the backside of Pd foil at a rate of $50 \mathrm{~cm}^{3} \mathrm{~min}^{-1}$, and the Ni surface was exposed to pure nitrogen. The electromotive force of the $\mathrm{ZrP}_{2.6} \mathrm{O}_{x}$ thin film electrolyte was measured by constructing the hydrogen concentration cell with $\mathrm{Ni} / \mathrm{Pd}\left|\mathrm{ZrP}_{2.6} \mathrm{O}_{x}\right|$ Pt configuration in order to estimate the transport number of proton. The hydrogen partial pressure on the $\mathrm{Pd}$ side, $p_{\mathrm{H} 2}(\mathrm{Pd})$, was kept at 1.0 atm by feeding $100 \% \mathrm{H}_{2}$ gas at a flow rate of $200 \mathrm{~cm}^{3} \mathrm{~min}^{-1}$. The hydrogen partial pressure on the $\mathrm{Pt}$ side, $p_{\mathrm{H} 2}(\mathrm{Pt})$, was varied from 0.1 to 0.8 atm by feeding $\mathrm{H}_{2} / \mathrm{Ar}$ mixed gas at a flow rate of $200 \mathrm{~cm}^{3} \mathrm{~min}^{-1}$.

\section{Results and Discussion}

Firstly, the cell of $\mathrm{Pt}\left|\mathrm{ZrP}_{2.6} \mathrm{O}_{x}\right| \mathrm{Pd}$ build up by depositing directly $\mathrm{ZrP}_{2.6} \mathrm{O}_{x}$ electrolyte on a $\mathrm{Pd}$ surface were examined, 
showing that the cell could not produce any open-circuit voltages owing to the electrical short-circuiting. It is clear that the surface of the Pd metal is deformed by exposing to hydrogen atmosphere at the temperature (Figs. 1a and $1 \mathrm{~b}$ ). Pd reacts with hydrogen and changes to $\alpha-\mathrm{PdH}$ phase at temperatures above ca. $300^{\circ} \mathrm{C}$. ${ }^{10}$ Consequently, the metal surafce largely deforms by the hydrogenation because the phase transition involves the $3 \%$ lattice expansion. ${ }^{10}$ $\mathrm{Ni}$ is hydrogen permeable with the permeability of smaller than that of Pd by three orders of magnitude. ${ }^{11}$ The capacity of hydrogen sorption in the former is smaller than that in the later by several orders of magnitude. ${ }^{11}$ Therefore, the lattice expansion of Ni by the hydrogenation is estimated to be negligibly small compared to that of Pd. Hence, Ni-deposited Pd anode, Ni/Pd, was implemented for the anode support. The Ni/Pd foil with the Ni layer of $600 \mathrm{~nm}$ thickness shows the hydrogen permeability of about $5 \times 10^{-9} \mathrm{~mol} \mathrm{~s}^{-1} \mathrm{~m}^{-1} \mathrm{~Pa}^{-0.5}$, which is a half of the permeability of the pure Pd foil. ${ }^{11}$ This value is sufficient to give the external current of at least $2 \mathrm{~A} \mathrm{~cm}^{-2}$ in a fuel cell.

Figure 1c shows the cross-sectional TEM image of the HMFC. The cell consists of four layers, comprising a top Pt particle layer, a $\mathrm{ZrP}_{2.6} \mathrm{O}_{x}$ thin film, a Ni interlayer of $600 \mathrm{~nm}$ and a $\mathrm{Pd}$ foil. The $\mathrm{ZrP}_{2.6} \mathrm{O}_{x}$ thin film electrolyte of $130 \mathrm{~nm}$ thickness is uniformly formed over the Ni layer. The electron diffraction patterns from a $\mathrm{ZrP}_{2.6} \mathrm{O}_{x}$ film show only the halo ring, indicating that the layer is amorphous phase. The cell with the $\mathrm{ZrP}_{2.6} \mathrm{O}_{x}$ thin film electrolyte on the $\mathrm{Ni} / \mathrm{Pd}$ anode clearly gives a stable open circuit voltage $(\mathrm{OCV})$ of about $1.0 \mathrm{~V}$ at $400^{\circ} \mathrm{C}$ (Fig. 2a). This value is close to the theoretical value of a fuel cell with air and hydrogen. The output voltage abruptly decreases with increasing the extract current flow, and the maximum extract current at a zero overload is limited to be less than $10 \mathrm{~mA} \mathrm{~cm}^{-2}$. Thus, the maximum power density at the temperature is about $0.8 \mathrm{~mW} \mathrm{~cm}{ }^{-2}$. The impedance response of the fuel cell at OCV reveals two distinct semicircle arcs in Cole-Cole plots and also reveals two peaks in complex impedance plane plot (Fig. $2 b$ ). The semicircles at the higher and lower frequency sides are hereafter identified as HS and LS, respectively. The high frequency
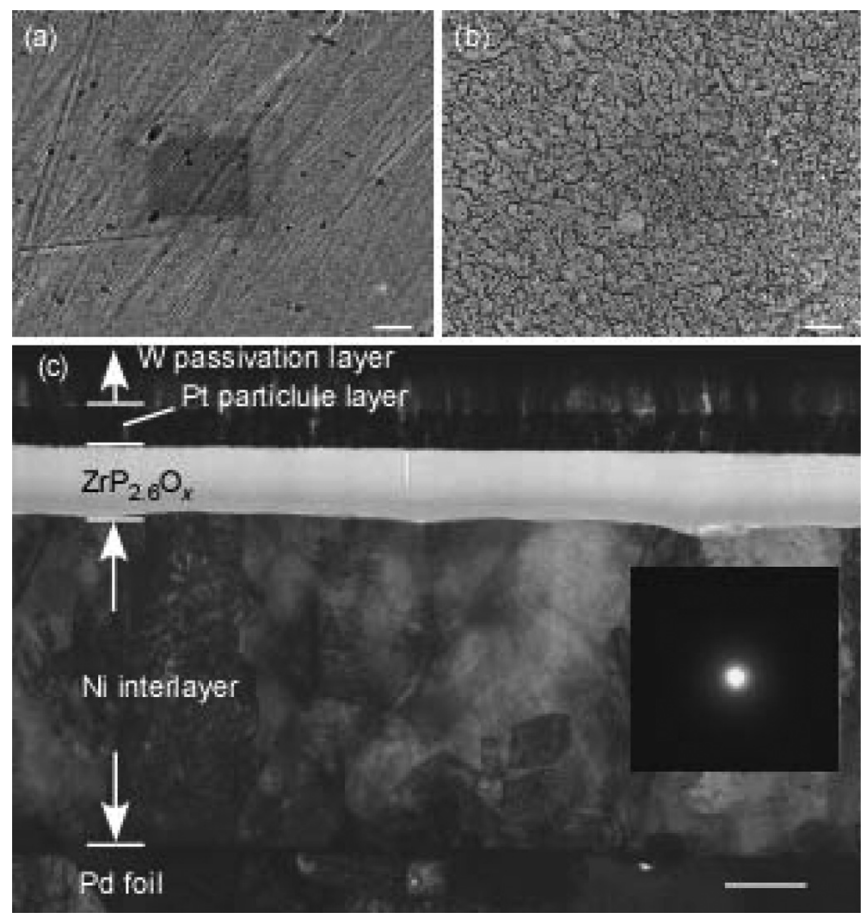

Figure 1. SEM images of the surface of Pd anode support (a) before and (b) after exposing to $50 \%-\mathrm{H}_{2} / \mathrm{Ar}$ gas at $400^{\circ} \mathrm{C}$ for $2 \mathrm{~h}$. (c) Cross-sectional TEM image of HMFC of $\mathrm{Ni} @ \mathrm{Pd}\left|\mathrm{ZrP}_{2.6} \mathrm{O}_{x}\right|$ Pt. The inset is area-selected electron diffraction pattern from the $\mathrm{ZrP}_{2.6} \mathrm{O}_{x}$ film. The scale bar in (a) and (b) is 1 $\mu \mathrm{m}$, and that in (c) is $150 \mathrm{~nm}$. intercept with the real axis represents a ohmic resistance $\left(R_{0}\right)$, whereas the HS and LS must correspond to a polarization resistance $\left(R_{\mathrm{p}}\right)$. The ohmic resistance is generally associated with the electrolyte resistance, and the value of this cell, $0.2 \Omega \mathrm{cm}^{2}$, is consistent with the value calculated from the proton conductivity of $\mathrm{ZrP}_{2.6} \mathrm{O}_{x}$ thin film $\left(7 \times 10^{5} \mathrm{~S} \mathrm{~cm}^{-2}\right.$ at $\left.400^{\circ} \mathrm{C}\right){ }^{7}$ The polarization is a major part of the whole resistances of cell and the $R_{\mathrm{p}}$ is about $120 \Omega \mathrm{cm}^{2}$ as determined by the difference between the high frequency intercept (HI) and low frequency intercept (LI). In order to deconvolute the parameters related to HS and LS, the equivalent circuit analysis was carried out with the model of $R_{0}\left(R_{1} Q_{1}\right)\left(R_{2} Q_{2}\right)$ shown in Fig. $2 \mathrm{c}$, where a constant phase element $Q$ is used as a pseudo-capacitance which is related to a true capacitance $C$ by the relation $C=R^{(1-n / n)} Q^{1 / n} \cdot{ }^{12}$ The two parallel components are related to HS and LS. Apparently, this simple model does not fit to the measured data (Fig. 2b),
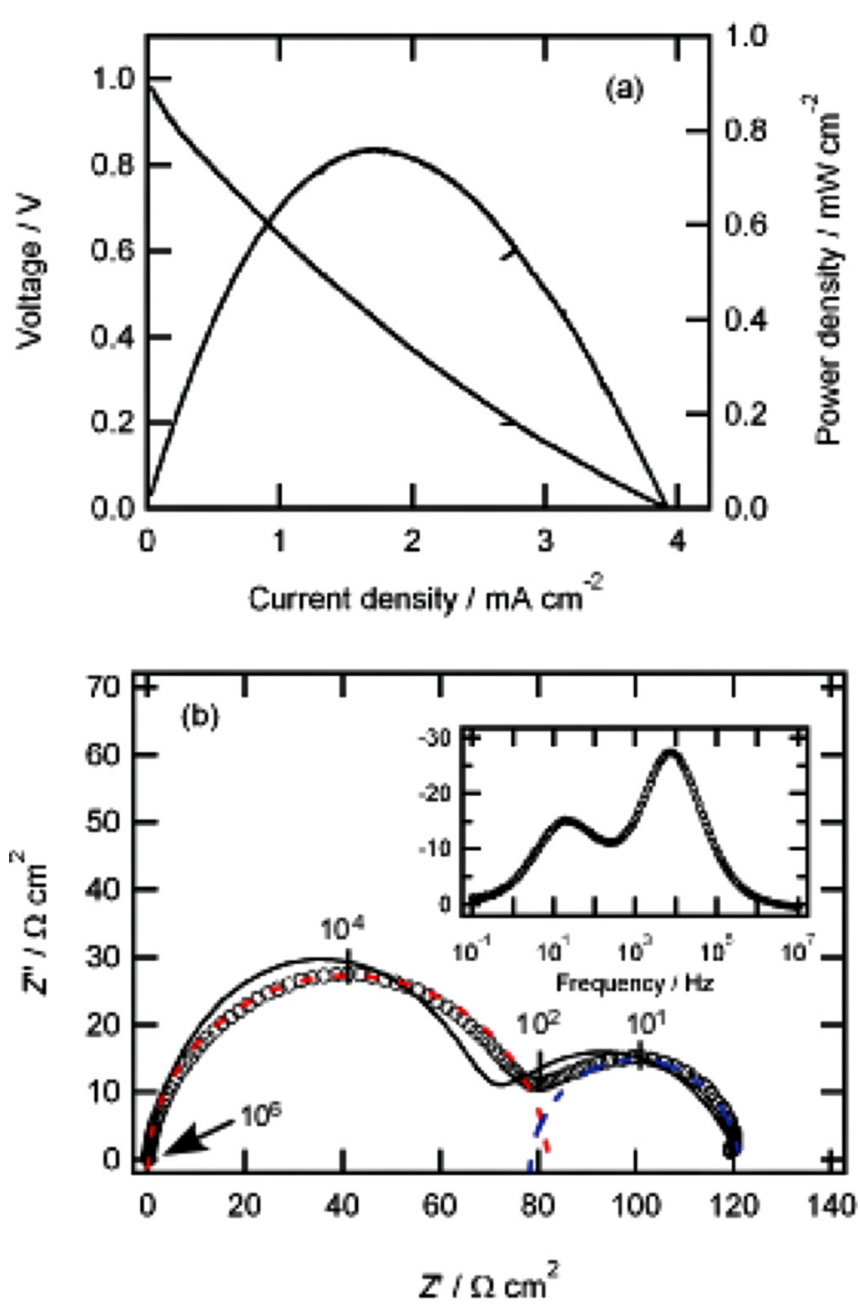

(c)

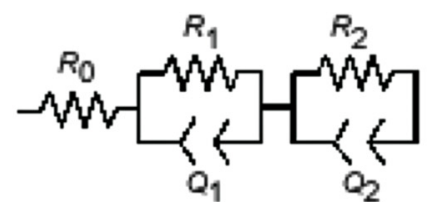

Figure 2. (Color online) (a) $I-V$ characteristics of a fuel cell, $\mathrm{H}_{2}\left(p_{\mathrm{H} 2}=0.5\right.$ atm), Ni@Pd $\left|\mathrm{ZrP}_{2.6} \mathrm{O}_{x}\right| \mathrm{Pt}$, air, at $400^{\circ} \mathrm{C}$. (b) Impedance response of the fuel cell at OCV. The solid line indicates the calculated curve with an equivalent circuit model depicted in (c). The semicircle drawn by red dashed line and blue dashed line is fitted to the high-frequancy semicircle (HS) and low-frequency semicircle (LS), respectively. (c) Equivalent circuit model. $R$ : resistance and $Q$ : pseudo capacitance (constant phase element). 
suggesting that the HS and/or LS involve some asymmetric factors. HS and LS can be fitted with a separate semicircle, respectively, as shown in Fig. 2b. The time constatnt of each semicircle, defined as $\mathrm{l}=R C$, can be determined from the maximum of the semicircle

$$
\omega R C=\omega t=1
$$

where $\omega$ is circular frequency. ${ }^{12}$ Assuming that the resistances of the HS and the LS components are corresponding to the daiameter of each semicircle fit, the capacitance of the HS, $C_{\mathrm{HS}}$, is estimated to be $\sim 10^{-6} \mathrm{~F} \mathrm{~cm}^{2}$, and that of the LS, $C_{\mathrm{LS}}, \sim 10^{-3} \mathrm{~F} \mathrm{~cm}^{2}$.

The polarization resistance of the HMFC may include the contributions of (i) low hydrogen diffusivity of the Ni interlayer, (ii) proton transport through solid-solid hetero junction at electrolyte/electrode interface, (iii) hydrogen dissociation reaction of the anode and (iv) reaction of $2 \mathrm{H}^{+}+1 / 2 \mathrm{O}_{2} \rightarrow \mathrm{H}_{2} \mathrm{O}$ at a triple phase boundary of cathode-electrolyte-gas. The kinetics of hydrogen dissociation reaction of $\mathrm{H}_{2} \Rightarrow 2 \mathrm{H}$ on Pd surface is very fast because the hydrogenation of Pd has a negative enthalpy, ${ }^{13}$ so that the contribution of this surface reaction can be negligible. Figure 3 indicates that the $I-V$ characteristics of the $\mathrm{Ni} / \mathrm{Pd}\left|\mathrm{ZrP}_{2.6} \mathrm{O}_{x}\right| \mathrm{Pt}$ cells with various thicknesses of the $\mathrm{Ni}$ interlayer. The $I-V$ relationship is not varied by changing the thickness from 80 to $1200 \mathrm{~nm}$, indicating that the low diffusivity of hydrogen through $\mathrm{Ni}((\mathrm{i}))$ is not responsible for the poralization resistances of the HMFC.

The resistances of the cell clearly change with the gas concentrations at cathode and anode (Fig. 4). The HS is slightly decreased by increasing $p_{\mathrm{O} 2}$ at cathode, even though the LS is not varied in the $p_{\mathrm{O} 2}$ range. Furthermore, the LS and $\mathrm{HS}$ are simultaneously decreased by increasing $p_{\mathrm{H} 2}$ at anode and the LS greatly decreases by one-third with increasing $p_{\mathrm{H} 2}$ at anode from 0.1 to 1.0. These results indicate that the anodic processes significantly contribute to a large polarization resistances of the cell. In order to further investigate the polarization at anode, the electrochemical properties were measured by modifying the hetero junction of anode/electrolyte (Fig. 5). The HS and LS of the cell with an ultrathin Pt anode surface layer (ca. $5 \mathrm{~nm}$ thickness), Pt@Ni/Pd $\left|\mathrm{ZrP}_{2.6} \mathrm{O}_{x}\right| \mathrm{Pt}$, become smaller than those of the cell without the Pt surface layer and the maximum power density increases by $40 \%$ even though OCV is slightly lower than $1.0 \mathrm{~V}$. When an ultrathin Pd layer is implemented, the HS and LS are effectively depressed and the maximum power density of the cell with the configuration of $\mathrm{Pd} @ \mathrm{Ni} / \mathrm{Pd}$ $\left|\mathrm{ZrP}_{2.6} \mathrm{O}_{x}\right| \mathrm{Pt}\left(1.8 \mathrm{~mW} \mathrm{~cm}^{-2}\right)$ is twice higher than that of $\mathrm{Ni} / \mathrm{Pd}$ $\left|\mathrm{ZrP}_{2.6} \mathrm{O}_{x}\right|$ Pt. These results strongly suggest that the electrochemical processes at the anode, which can be assigned to the proton transfer

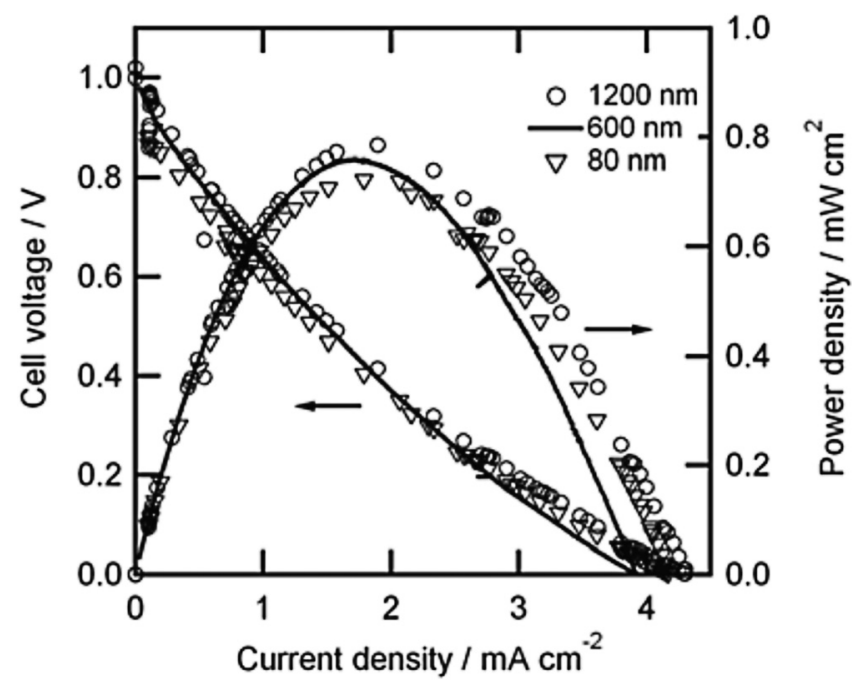

Figure 3. $I-V$ characteristics of $\mathrm{H}_{2}, \mathrm{Ni} @ \mathrm{Pd}\left|\mathrm{ZrP}_{2.6} \mathrm{O}_{x}\right| \mathrm{Pt}$, air fuel cell with various thicknesses of $\mathrm{Ni}$ interlayer.
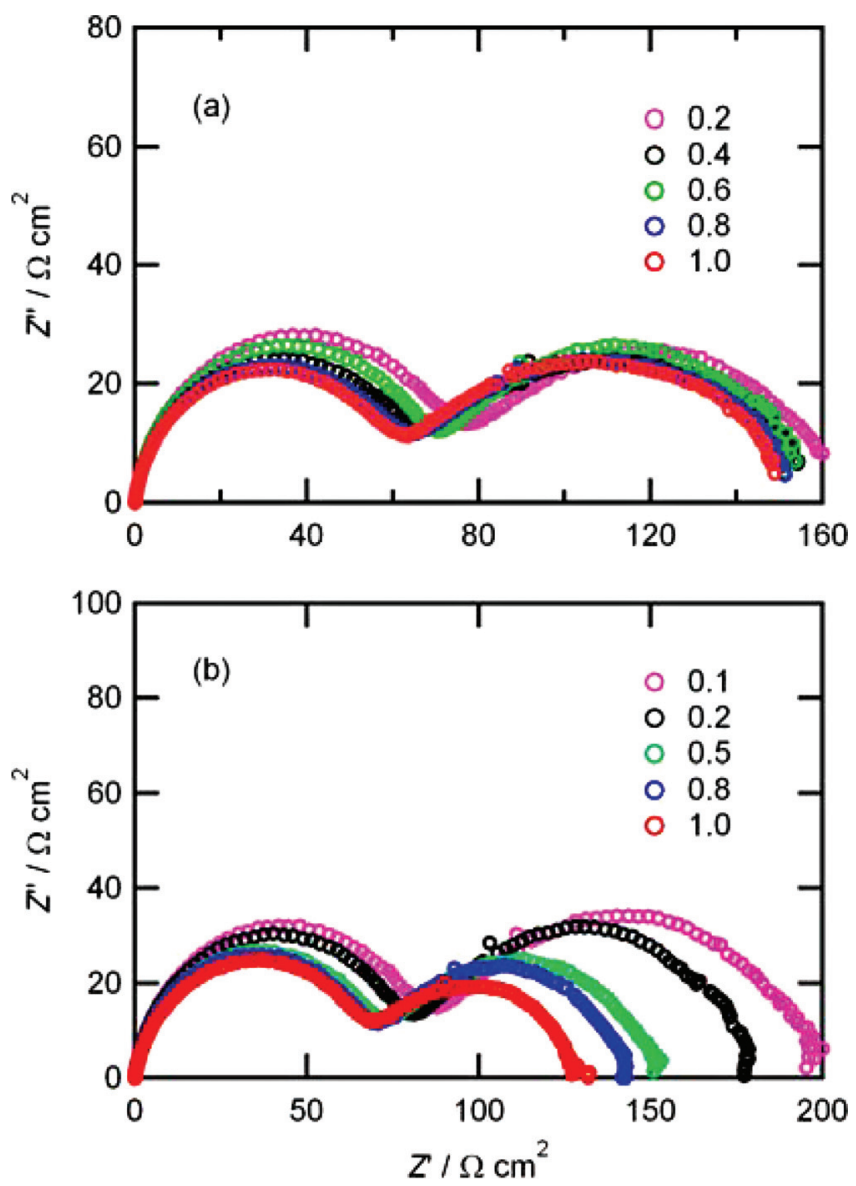

Figure 4. (Color online) (a) Impedance responses at $\mathrm{OCV}$ of $\mathrm{H}_{2}, \mathrm{Ni@Pd}$ $\left|\mathrm{ZrP}_{2.6} \mathrm{O}_{x}\right| \mathrm{Pt}, p_{\mathrm{O} 2}(\mathrm{Pt})$ fuel cell at $400^{\circ} \mathrm{C}$ with changing oxygen partial pressure at cathode, $p_{\mathrm{O} 2}(\mathrm{Pt})$, from 0.1 to 1.0. (b) Impedance responses at $\mathrm{OCV}$ of $\mathrm{H}_{2}, \mathrm{Ni} @ \mathrm{Pd}\left|\mathrm{ZrP}_{2.6} \mathrm{O}_{x}\right| \mathrm{Pt}$, air fuel cell at $400^{\circ} \mathrm{C}$ with changing hydrogen partial pressure at anode, $p_{\mathrm{H} 2}(\mathrm{Pd})$, from 0.2 to 1.0 .

across the hetero interface between the metal anode and the oxide electrolyte and to the hydrogen dissociation reaction of the anode, are responsible for both HS and LS.

In many cases of SOFC, the cathodic polarization is predominant in the total overpotentials. ${ }^{14-18}$ The polarization resistance of our HMFC is much larger than those reported for the various thin film SOFC operating at around $400^{\circ} \mathrm{C}$ by 1 or 2 orders of magnitude, $, 2,6$ and is less sensitive to the $p_{\mathrm{O} 2}$ at the cathode. Hence, the cathodic polarization is not rate limiting step in the current cell. It is reported that the SOFC with mixed conducting $\mathrm{La}_{1-x} \mathrm{Sr}_{x} M \mathrm{O}_{3}$ cathode $(M=\mathrm{Mn}, \mathrm{Co})$ and YSZ electrolyte reveal the large polarization associated with the oxide ion transfer across the cathode/electrolyte interface because the poorly ion-conducting, secondary phase such as $\mathrm{Zr}_{2} \mathrm{La}_{2} \mathrm{O}_{7}$, is formed by the reaction of $\mathrm{La}_{1-x} \mathrm{Sr}_{x} M \mathrm{O}_{3}$ and YSZ. ${ }^{14,19,20}$ The related capacitance is in order of $10^{-6} \mathrm{~F}$ $\mathrm{cm}^{2} .{ }^{14,19,20}$ This value is in agreement with $C_{\mathrm{HS}}$ of our cell. Acordingly, HS can be associated with the interfacial proton transfer at anode/electrolyte interface, if the poorly proton conducting layer exists at the interface. The SOFC with a mixed conducting oxide cathode reveals the large cathode polarization with the relatively-large pseudo capacitance, so-called chemical capacitance of $>10^{-1} \mathrm{~F}$ $\mathrm{cm}^{2}$, which is associated with the oxygen stoichiometry change of the cathode materials. ${ }^{14,18}$ On the other hand, Martin et al. reported that the hydrogen sorption by a Pd thin film in alkaline solution reveals the pseudo-capacitance of about $10^{-4}-10^{-3} \mathrm{~F} \mathrm{~cm}^{-2}$, associated with the hydrogenation of $\mathrm{Pd} .^{13,21}$ This value is similar to the $C_{\mathrm{LS}}$, indicating that the $\mathrm{LS}$ might be related to the redox reaction of the anode metal. The anodic reaction of HMFC is given by Eq. 2 

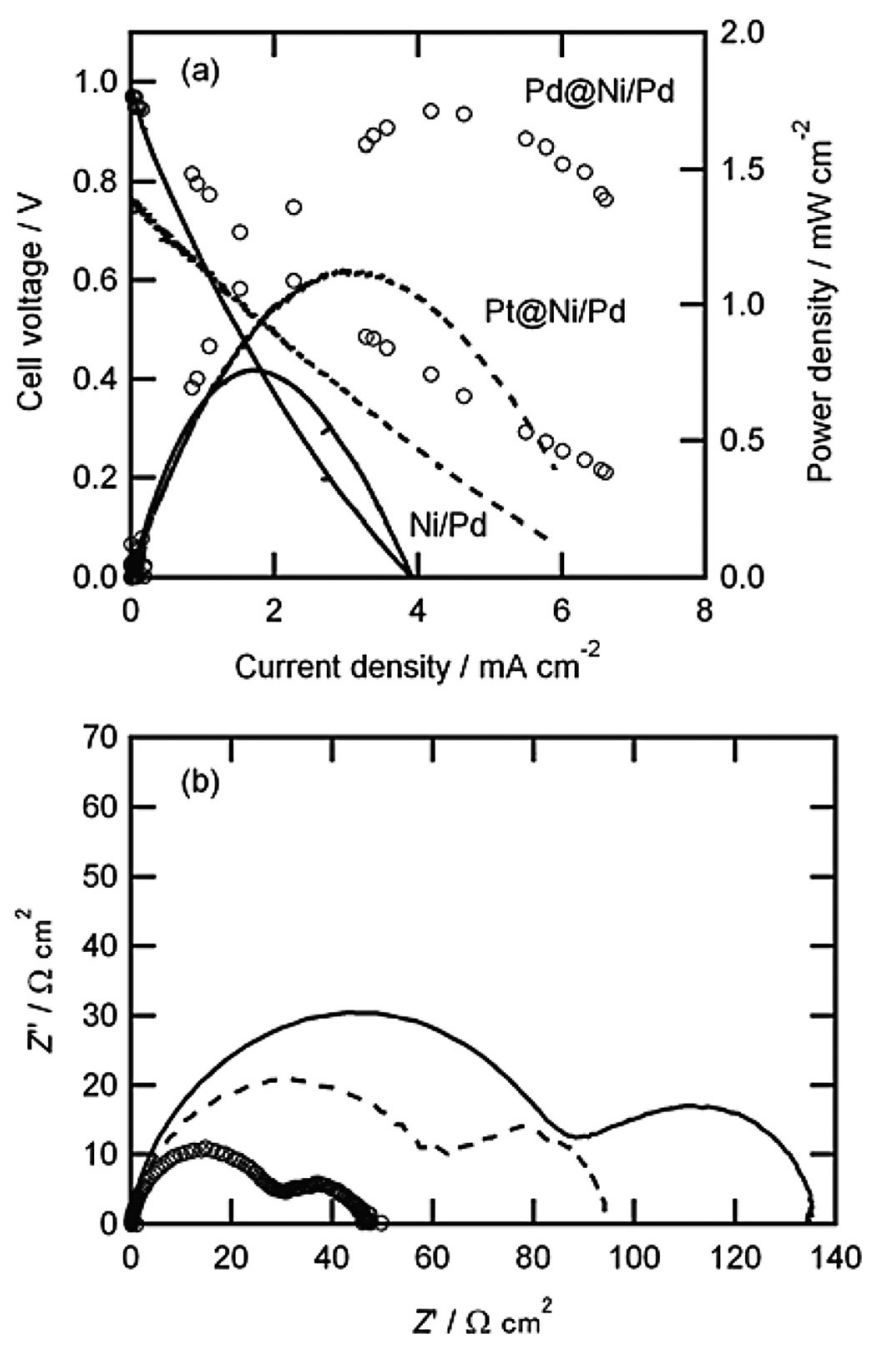

Figure 5. (a) $I-V$ characteristics at $400^{\circ} \mathrm{C}$ of the HMFC formed on anodes of $\mathrm{Ni} / \mathrm{Pd}, \mathrm{Pt} @ \mathrm{Ni} / \mathrm{Pd}$ and Pd@NiPd. (b) impedance responses of the cell at OCV. The black, yellow and pink show Ni/Pd, Pt@Ni/Pd and Pd@NiPd, respectively. The cell with an anode of Ni/Pd (-), Pt@Ni/Pd(- - -) and Pd@NiPd $(\bigcirc)$.

$$
\mathrm{MH} \leftrightarrows \mathrm{H}^{+}+\mathrm{M}+\mathrm{e}^{-}
$$

As menthioned before, the bulk diffusion process of this reaction is very fast, so that the hydrogen dissociation (oxidation) of the HM anode in vicinity of the anode/electrolyte interface are speculated to be rate limiting for the anode reaction of the current HMFC.

There are several possible explanations of the large interfacial polarization at an anode side. The oxide ion transport from cathode to anode, if amorphous $\mathrm{ZrP}_{2.6} \mathrm{O}_{x}$ film shows, facilitates the evolution of $\mathrm{H}_{2} \mathrm{O}$ at the anode/electrolyte hetero interface. Such a reaction may increase the impedance at the interface because the electrolyte can be detached from anode by the evolved water gas and the contact areas required for the proton transfer and anodic reaction must be decreased. The hydrogen concentration cell with a configuration of $p_{\mathrm{H} 2}(\mathrm{Pd})=1.0, \mathrm{Ni} / \mathrm{Pd}\left|\mathrm{ZrP}_{2.6} \mathrm{O}_{x}\right| \mathrm{Pt}, p_{\mathrm{H} 2}(\mathrm{Pt})=0.1-0.8$ was constructed in order to estimate the transport number of proton in $\mathrm{ZrP}_{2.6} \mathrm{O}_{x}$ electrolyte (Fig. 6). EMF of this cell can be represented by Nernst equation ${ }^{22}$

$$
E M F=-t_{H} \frac{k T}{2 e} \ln \left(\frac{p_{H 2}(P t)}{p_{H 2}(P d)}\right)-t_{H} \frac{k T}{2 e} \ln \left(\frac{\gamma_{H 2}(P t)}{\gamma_{H 2}(P d)}\right)
$$

Here, $t_{\mathrm{H}}$ is a transport number of proton, $\gamma_{\mathrm{H} 2}(\mathrm{Pd})$ is an activity coefficient of hydrogen inside the anode metal, and $\gamma_{\mathrm{H} 2}(\mathrm{Pt})$ is an activity

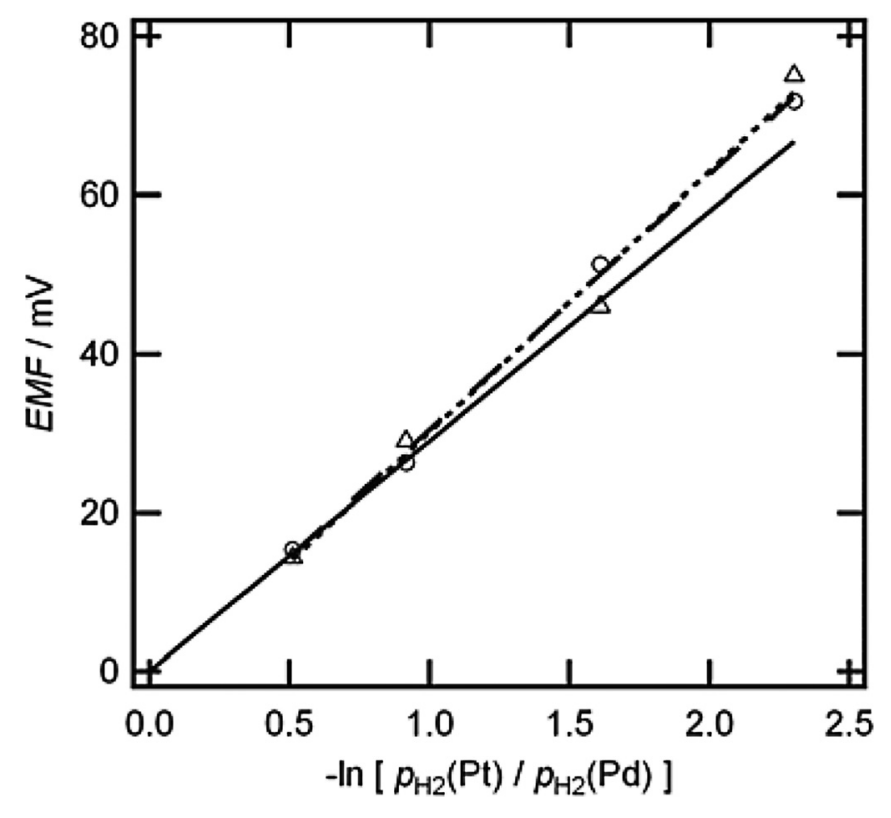

Figure 6. Electromotive force of hydrogen concentration cell with a configuration of $\mathrm{H}_{2}\left(\mathrm{p}_{\mathrm{H} 2}=1\right), \mathrm{Ni} @ \mathrm{Pd}\left|\mathrm{ZrP}_{2.6} \mathrm{O}_{x}\right| \mathrm{Pt}, p_{\mathrm{H} 2}(\mathrm{Pt})=0.1-0.8$ atm. The black solid line indicates the theoretical $E M F$ given by Eq. 3 (see text). The measured $(\bigcirc)$ and the calculated slope (- - -) of $E M F$ in wet condition. The measured $(\triangle)$ and the calculated slope $(\ldots \ldots)$ of $E M F$ in dry condition.

coefficient of hydrogen gas at Pt cathode, namely, 1.0. The solid line in Fig. 6 is the calculated by Eq. 3 when $t_{\mathrm{H}}$ and $\gamma_{\mathrm{H} 2}(\mathrm{Pd})$ are assumed to be 1.0. $\gamma_{\mathrm{H} 2}(\mathrm{Pd})$ in our set up is unknown, whereas a slope of $E M F$ plots must be similar to that of the theoretical line if $t_{\mathrm{H}}=1.0 . \mathrm{ZrP}_{2.6} \mathrm{O}_{x}$ film gives the $E M F$ value in general agreement with the theoretical value and $t_{\mathrm{H}}$ determined from the slopes are 1.1 even in dry and wet atmospheres. These results suggest that the contribution of an oxide ion and an electron to the charge carriers in the $\mathrm{ZrP}_{2.6} \mathrm{O}_{x}$ is negligibly small in comparison with that of a proton. The large anodic polarization in our HMFC is not related to the water evolution at the solid-solid hetero interface.

A potential barrier for the proton transfer across the interface can be formed due to the space charge effect. ${ }^{23}$ In fact, Matsumoto et al. reported that the depletion layer of protonic carriers is formed at boundary region between noble metal and proton-conducting $\mathrm{BaZrO}_{3}$ electrolyte because of the carrier redistribution for the energy level alignment between the Fermi energy of electrolyte and work function of electrode. ${ }^{24} \mathrm{Ni}$ metal tends to form the thermallyoxidized film on the surface at elevated temperatures. ${ }^{25}$ Thus, the passive layer of a nickel oxide or a nickel phosphate are speculated to form at the interface of $\mathrm{ZrP}_{2.6} \mathrm{O}_{x}$ and $\mathrm{Ni}$ anode. If these possess the low proton conductivity and the slow kinetics of the protonation through the redox of Ni species, the large anodic polarization must be involved because the hydrogen dissociation and the following proton transfer at the interface are limited. A more comprehensive understanding of the electrochemistry at a hetero interface should be paid to develop the amorphous thin-film electrolyte fuel cell enabling the efficient transfer of protons through the interfacial layer.

\section{Conclusion}

In summary, the hydrogen permeable membrane fuel cell based on the $100 \mathrm{~nm}$-thick membrane of amorphous $\mathrm{ZrP}_{2.6} \mathrm{O}_{x}$ electrolyte successfully operates at $400^{\circ} \mathrm{C}$. The electrolyte reveals the protonic transport number of unity without electronic leakage in fuel cell conditions. Hence, this thin film-type fuel cell can exhibit the stable OCV of $1.0 \mathrm{~V}$ similar to the theoretical value. The maximum power density is still limited and is about $2 \mathrm{~mW} \mathrm{~cm}^{-2}$ because of the large polarization related to the proton transfer and the oxidative reaction 
of metal hydride at anode/electrolyte hetero interfaces. It is concluded that amorphous $\mathrm{ZrP}_{2.6} \mathrm{O}_{x}$ thin film is promising as a gas-tight electrolyte exhibiting the pure proton conduction in the intermediate temperature range.

\section{Acknowledgment}

This work was financially supported by the Grant-in-Aid of JSPS for Scientific Research on Young Scientists (A) and by the Global COE Program (Project No. B01: Catalysis as the Basis for Innovation in Materials Science) from the Ministry of Education, Culture, Sports, Science and Technology, Japan.

\section{References}

1. J. H. Shim, C.-C. Chao, H. Huang, and F. B. Prinz, Chem. Mater., 19, 3850 (2007).

2. H. Huang, M. Nakamura, P. Su, R. Fasching, Y. Saito, and F. B. Prinz, J. Electrochem. Soc., 154, B20 (2007).

3. S. Rey-Mermet, P. Muralt, N. R. Bieri, N. Hotz, M. J. Stutz, D. Poulikakos, P. Heeb, P. Muller, A. Bernard, R. Gmur et al., J. Power Sources, 177, 123 (2008).

4. X. Chen, N. J. Wu, L. Smith, and A. Ignatiev, Appl. Phys. Lett., 84, 2700 (2004).

5. B.-L. Lai, K. Kerman, and S. Ramanthan, J. Power Sources, 196, 1826 (2011).

6. B.-L. Lai, K. Kerman, and S. Ramanthan, J. Power Sources, 196, 2068 (2011).
7. Y. Aoki, K. Ogawa, H. Habazaki, S. Nagata, Y. Li, T. Kunitake, and S. Yamaguchi, Chem. Mater., 22, 5528 (2010).

8. N. Ito, M. Iijima, K. Kimura, and S. Iguchi, J. Power Sources, 152, 200 (2005).

9. N. Ito, S. Aoyama, T. Matsui, S. Matsumoto, H. Matsumoto, and T. Ishihara, J. Power Sources, 185, 922 (2008).

10. E. Wicke and H. Brodowsky, in Hydrogen in Metals II, G. Alefeld and J. Völkl, Editors, Springer, Berlin (1978).

11. K. Yamakawa, M. Ege, B. Ludescher, M. Hirscher, and H. Kronmüller, J. Alloys Compd. 321, 17 (2001).

12. J. T. S. Irvine, D. C. Sinclair, and A. R. West, Adv. Mater., 2, 132 (1990).

13. M. H. Martin and A. Lasia, Electrochim. Acta, 53, 6317 (2008).

14. S. B. Adler, Chem. Rev., 104, 4791 (2004).

15. T. Kawada, J. Suzuki, M. Sase, A. Kaimai, K. Yashiro, Y. Nigara, J. Mizusaki, K. Kawamura, and H. Yugami, J. Electrochem. Soc., 149, E252 (2002).

16. A. Mitterdorfer and L. J. Gauckler, Solid State Ionics, 120, 211 (1999).

17. K. Yashiro, T. Nakamura, M. Sase, F. Hermes, K. Sato, T. Kawada, and J. Mizusaki, Electrochem. Solid State Lett., 12, B135 (2009).

18. S. B. Adler, Solid State Ionics, 111, 125 (1998).

19. Y. L. Yang, A. J. Jacobson, C. L. Chen, G. P. Luo, K. D. Ross, and C. W. Chu, Appl. Phys. Lett., 79, 776 (2001).

20. A. Mitterdorfer and L. J. Gauckler, Solid State Ionics, 111, 185 (1998).

21. L. Birry and A. Lasia, Electrochim. Acta, 51, 3356 (2006).

22. D. P. Sutija, T. Norby, and P. Björnbom, Solid State Ionics, 77, 167 (1995).

23. J. Maier, Prog. Solid State Chem., 23, 171 (1995).

24. H. Matsumoto, Y. Furuya, S. Okada, T. Tanji, and T. Ishihara, Electrochem. Solid State Lett., 10, P11 (2007).

25. S. V. Kumari, M. Natarajan, and V. K. Vaidyan, J. Mater. Sci. Lett., 11, 761 (1992). 